FELIX JAITNER - TOBIAS SPÖRI ${ }^{1}$

THE TIP OF THE ICEBERG?

Protest and crisis-prone development in Central and Eastern Europe since $1989^{2}$

DOI: $10.18030 /$ SOCIO.HU.2017EN.7

\title{
ABSTRACT
}

Since the outbreak of the financial and economic crisis in 2008, protests against austerity and raising social inequality have increasingly taken place in many regions of the world. Central and Eastern Europe is one of those regions, and has recently experienced several large-scale protest movements. These protests were partially triggered by intensified austerity measures, higher unemployment rates and growing dissatisfaction with democracy. However, the particular reasons to protest are diverse, ranging from environmental to social or anti-corruption issues.

Despite the differences that exist in Central and Eastern Europe countries, we argue that they share a common pattern in terms of the societal environment of protest. As a first step, we will critically assess the forms of protest participation in Central and Eastern Europe and map out common features of the identified crisis-prone development since 1989. In the subsequent part, we will argue that such features as the growing gap between the political elite and citizens, harsh individual economic conditions and a high level of frustrated expectations have become more visible and have heavily contributed to the increasing unrest.

We conclude that the crisis-prone development since 1989 has created an ambivalent ecology of protest in Central and Eastern Europe. The vast majority of citizens face economic hardship and do not have the means to interfere with or participate in democratic processes as effectively as the political and economic elites do. A growing number of citizens, however, appear to be more willing to raise their voices visibly in public. Secondly, the increase in protests indicates a deeper societal crisis. In this sense, Central and Eastern Europe can be understood as a "laboratory" for testing the social conditions of democracy.

Keywords: Central and Eastern Europe, protest, crisis, transformation

1 Felix Jaitner, Department of Political Science, University of Vienna. Tobias Spöri Department of Political Science, University of Vienna. The authors contributed equally to this work.

2 We would like to thank the organizers and participants of the workshop titled Civil Society and Social movements in the changing democracies of Central and Eastern Europe, held at the Centre for Social Sciences, Hungarian Academy of Sciences, Budapest (May 11-12, 2017). We would also like to thank the reviewers, as well as our colleague Titus Udrea for their valuable comments and suggestions. 
FELIX JAITNER - TOBIAS SPÖRI

\section{THE TIP OF THE ICEBERG?}

Protest and crisis-prone development in Central and Eastern Europe since 1989

\section{PROTEST IN THE PAST yeARS IN CENTRAL AND EASTERn EUROPE}

Since the outbreak of the financial and economic crisis in 2008, Southern European countries have received substantial scholarly and public attention. However, Central and Eastern Europe ${ }^{3}$ has been equally affected by the crisis through intensified austerity measures, higher unemployment rates and increasing dissatisfaction with democracy. Similar to Southern Europe, Central and Eastern Europe has experienced several large-scale protest movements in recent years. The reasons for citizens to protest are fairly diverse, ranging from single-issue protests ${ }^{4}$ to broader protest movements against the political establishment. ${ }^{5}$ These - in a long and diverse list of protests - represent the starting point of this article. Although large-scale protests are not a new phenomenon in Central and Eastern Europe, they have emerged within a relatively new international constellation: the global economic crisis and a global increase in protest.

At first glance, the protests in the region taking place in times of economic decline seem to share comparable features, such as claiming similar policy changes in favour of democracy, addressing the growing gap between representatives and the people, and experiencing equal reactions from the political elite. However, parallel to such protests, right-wing and anti-pluralistic protests are also growing, particularly in Central and Eastern Europe. Right-wing protests frame their claims in an allegedly democratic way and demand more citizen participation, although their messages are anti-pluralistic. In the last years, protests in the region have increased and have become more diverse.

The purpose of this paper is to identify a regional pattern of crisis-prone development in Central and Eastern Europe in order to grasp the ecology of protest. We present a theoretical argument, stating that the increase of protest indicates a deeper societal crisis, which is rooted in the development since 1989. We argue that, like a floating iceberg, the growing number of protests is just the visible tip of the crisis-prone development. Recently, the effects of such crisis-prone development have become more visible and have contributed heavily to the increase in the number of protests. We do not seek to study protest movements as such (that is, we don't aim to introduce a new classification of diverse protest movements). Instead, we take the increase in protests as the starting point of our argument and introduce new theoretical stances, such as the concept of "multiple crises," which we argue are not yet sufficiently discussed in the literature.

3 The analysis includes all former socialist countries in Europe, which are currently members of the European Union, i.e. Bulgaria, Croatia, the Czech Republic, Estonia, Hungary, Latvia, Lithuania, Poland, Romania, Slovakia and Slovenia.

4 E.g. the environmental activism in Romania (2013) or movements against same-sex marriage in Croatia (2014).

5 E.g. in Slovenia (2012-2013), Bulgaria (2013), Poland (2016-17) or Romania (2017). 
We start our argument by briefly discussing approaches to protest participation in the region from the literature on political participation in Central and Eastern Europe. Secondly, we assess the crisis-prone development over of the comprehensive transformation after 1989, including the economic crisis, since 2008. The focus thereby is on the crisis-prone development, which has created an ambivalent ecology of protest in Central and Eastern Europe. We examine identity crises in the spheres of politics, the economy and society. In political terms, Central and Eastern Europe has been experiencing a crisis of representation (decreasing turnout, low trust in institutions and the political elite, disenchantment with politics, bad governance, clientelism and corruption) as well as a crisis of liberal democracy (a lack of checks and balances), a decline the in independence of the media and growing authoritarian tendencies.

Concerning the economy, Central and Eastern European economies are "dependent market economies". Due to the dependency on Western European economies, such peripheral economies are likely to reduce social standards in order to attract foreign direct investments and are more vulnerable to economic crises. Regarding society, the transformation since 1989 has caused a high level of social inequality, mainly due to the reorganisation of the welfare state. Therefore, many citizens face individual economic hardships and have become dissatisfied with the political and economic development since 1989. This in turn makes them likely to follow populist promises or alternative development models such as "illiberal democracy".

Subsequently, we argue that the increased number of protests indicates a deeper crisis, which has become more visible in recent years. By translating Alex Demirovićs concept of "multiple crises" to Central and Eastern Europe, we stress that protest hints at a deeper, multi-facetted crisis, which threatens the sustainability of democracy in the region. The recent increase in protest is a reaction to the manifold features of the particular crisis-prone development in Central and Eastern Europe.

\section{Protest participation in Central and EAstern Europe}

Our understanding of protest participation is based on Teorell et al. (2007). Any form of protest is an example of "extra-representational forms" of political participation (i.e. forms of political participation taking place outside of the classical realm of representative democracy). Protest occurs most commonly when a substantial proportion of citizens seek policy change or fundamentally refuses governmental decisions; hence they will support certain interests, which are not sufficiently represented by political parties, or they will not have sufficient trust in them (Braun-Hutter 2014, Chesters-Welsh 2011, Harrebye-Ejrnæs 2015). The underlying assumption is that if citizens disagree with certain policies or the political system as such, they tend to raise their concerns directly and seek to influence political outcomes, representatives, civil society's stakeholders or like-minded people, which might take place in the streets or online (Norris 2002).

Taking into account the literature on political participation within Central and Eastern Europe, the recent increase in protests might have surprised some observers. Compared to old democracies, political participation in Central and Eastern Europe is portrayed as relatively weak: citizens are less willing to join associations and are more likely to be politically apathetic (Barnes 2006, Kostelka 2014, Letki 2004). Civic traditions are considered "less salient" and civil society is weakly developed (Howard 2002, Janmaat 2006). The dominant explanation for 
this weakness tends to stress the heritage of state socialism. The key argument of this approach is that citizens share "a lack of participation due to the long authoritarian experience" (Barnes 2006), which has "caused an attitudinal legacy" that is responsible for citizens' abstention from participation (Pop-Eleches-Tucker 2013). In this regard, socialisation under an authoritarian regime is crucial when it comes to explaining modern political behaviour (Killingsworth 2012: 142, Naimark-Gibianskii 1997).

Most of the studies arguing about the importance of a strong socialist heritage refer to weak political engagement through representational channels such as participating in elections, parties or other political organizations. When it comes to assessing political participation in in Central and Eastern Europe, protest participation is taken less into account, although it has a long and partially disregarded tradition, which heavily shaped the region even before $1989 .{ }^{6}$ In order to fully grasp the development of political participation in Central and Eastern Europe and elsewhere, it is necessary to include diverse forms of political participation in the assessment.

Over the last years, a growing number of scholars have challenged the dominant explanation for weak political participation, linking it to the socialist heritage by highlighting the striking effects of the transformation starting in 1989. Segert (2013) points out that both the "state socialist legacy" and the "legacy of the radical transformation processes" have had a great impact on the current development of the region. Mishler and Rose (1997: 434) argue that the effects of the latest economic and political performance are at least equally crucial for political participation, as is the socialist past. Tanasoiu (2013: 601-604) highlights the frustration of most citizens which stems from the transformation, along with the increasing disappointment towards the political elite, flourishing corruption or simply from unfulfilled and overly high expectations. Hooghe and Quintelier (2014: 221) even claim that the effects of socialisation under socialism are "rendered non-significant" when it comes to citizens' current experiences with bad governance, particularly in terms of high levels of corruption.

The transformation since 1989 has heavily shaped the ecology of protest. In this sense, the next part of the paper will highlight the crisis-prone development since 1989. The symptoms of this development have become more visible since the emergence of the economic crisis in 2008. We argue that this crisis-prone development has created a distinct regional pattern of protest.

\section{A REGIONAL PATTERN OF CRISIS-PRONE DEVELOPMENT}

in this part of the paper, we seek to determine a common pattern of crisis-prone development in Central and Eastern Europe, which contributes to and reinforces general outcomes of the transformation process. The focus will be on major changes in the spheres of politics, the economy and society. These spheres are interconnected (i.e. the transformation of one sphere affects the others).

Although we acknowledge specific national and sub-regional characteristics and differences, we argue that all respective countries share similar trends stemming from the transformation, which shape their development up to this day. Additionally, we do not argue that we should portray the development of the

6 Examples are the Hungarian Revolution of 1956, the Prague Spring, Solidarność, the Baltic independent movement and the Monday Demonstrations in the GDR. 
region since 1989 in a predominantly negative way. The aim of the paper is not to assess the transformation over recent decades as a whole; ${ }^{7}$ instead, we want to pinpoint certain issues, which have emerged from the transformation process and have resulted in what we call crisis-prone development. ${ }^{8}$ As we do not share the view that there is a linear pathway to democracy, our understanding of the transformation since 1989 deviates from the transition-to-democracy paradigm (Diamond et al. 2014, Elster et al. 1998). Instead, we argue that the region's crisis-prone development has been rooted in the "bumpy road" to a democratic and market economic system over the last two decades. The outbreak of the economic crisis in 2008 reinforced these deep-seated contradictions, and the symptoms of the crisis-prone development have become more visible since then.

\section{CRISIS-PRONE DEVELOPMENT IN THE SPHERE OF POLITICS}

one of the greatest challenges at the beginning of the political transformation was to establish democratic institutions such as constitutions, free elections, independent courts of justice, pluralistic party systems and free media: institutions which are clearly linked to the classical criteria of the democratic nation state. Soon, it became apparent that this process did not proceed easily (Kitschelt 1995, Ishiyama 1997).

The end of state socialism triggered a reorganisation of the nation state, which partially questioned the end of multi-ethnical statehood in Central and Eastern Europe. The dissolution of multinational states, such as Czechoslovakia or Yugoslavia, was followed by a "great reconfiguration" (Brubaker 2011: 1,786). This meant the formation of nation states with a dominant core nation. The new economic and political elite receives legitimacy by defining themselves as part of the core nation and often also portraying themselves as anti-communist. This, however, does not necessarily include an avowal to democratic values in itself. In order to strengthen and legitimise the new emerging nation states, nationalising discourses and policies were constructed, which often resulted in exclusive politics towards minorities, for example in the Baltic states (ibid: 1,789-1,802) or even war in the case of Yugoslavia. The outbreak of the economic crisis in 2008 and the subsequent implementation of austerity policies has reinforced this development, through nationalizing discourses, increasing social inequality and growing distrust in democratic institutions.

In terms of parties and representatives, the former are not as deeply rooted in society. This is turn causes high voter volatility, low levels of legitimacy and trust in parties (Wessels-Klingemann 2006) and antiestablishment sentiments towards the political elite. Citizens are likely to perceive the political elite as alienated and corrupt (Tanasoiu 2013). Parts of the political elite do not respond effectively to urgent societal problems such as social inequality. Forms of bad governance, clientelistic networks and a high level of corruption created an environment of distrust, frustration and disenchantment with politics, which led to a severe crisis of representation.

7 For a comprehensive and well-balanced overview of the early phases of the transformation, see Kornai (2006).

8 The discussion of issues stemming from the comprehensive transformation started almost parallel to the actual transformation process. In the early 1990s, Offe (1991) highlighted the multiple challenges of the transformation process for the former state-socialist societies by introducing the term "dilemma of simultaneity" to the debate. 


\section{CRISIS-PRONE DEVELOPMENT IN THE SPHERE OF THE ECONOMY}

one of the major goals of the economic transformation was to catch up with the economic development levels of "Western" market economies. Instead, a process of "peripheralisation" has shaped the development of all former state-socialist countries since the 1990s. From a political economy perspective, the term "peripheralisation" describes an increasing dependency on the countries of the capitalist core in terms of economic relations, such as investment, company ownership, terms of trade and technological know-how. In peripheral economies, it is usually a limited part of the population that exclusively depends on wage incomes (Becker et al. 2010). Therefore, forms of wage labour and multiple subsistence economies are often combined. Active extraversion, a combination of export-orientation and export surplus, is a characteristic feature of dominant economies. Peripheral economies on the other hand, are usually characterized by high import dependence, at least in key areas (intraversion). ${ }^{9}$

Within the region, the degree of peripheralisation differs. The new EU member states, especially the Visegrád group (the Czech Republic, Hungary, Poland and Slovakia), were incorporated as "dependent market economies" into the Western industrial production process (Nölke-Vliegenthart 2009). A distinct division of labour has developed between the old and the new EU member states. Know-how, complex production facilities and research and development are concentrated in Western Europe. Production is partly outsourced to the newer members (Popławski 2016).

The Visegrád group and Slovenia can be described as foreign-led economies, with foreign control over leading export industries and most of the public utilities. Moreover, one can observe a high level of foreign dominance in the financial sector, which makes the Central and Eastern European economies extremely vulnerable to external economic shocks (Becker-Jäger 2012, Myant-Drahokoupil 2013). In contrast to the aforementioned countries, a greater level of deindustrialisation and the emergence of a disproportionally large financial sector has marked the development of the remaining former Yugoslav republics, Bulgaria, Romania, and the Baltic states. The "financialisation" of the national economies has made these countries even more vulnerable to external crises (Bērziṇš 2014, Galgóczi 2009, Schreiner 2010).

However, peripheralisation should not be reduced to a mere economic process, as it has far-reaching social and political implications. Analysing state strategies in the Visegrád countries since the 2000 s, Drahokoupil concludes: "The dominant state strategies aim at promoting competitiveness by attracting foreign investment" (2008: 175). Policies are geared towards attracting foreign capital through appropriate economic policies. This creates a lot of pressure on the government to reduce social standards in order to maintain low labour costs or to offer transnational companies tax breaks, which subsequently intensifies the crisis-prone development.

The global economic crisis in 2008 demonstrated again that the development model emerging from the transformation process was highly volatile ${ }^{10}$ and vulnerable to external shocks. All Central and Eastern

9 "Intraverted accumulation is centred on the domestic market, whereas extraversion implies a strong outward orientation of trade as well as flows of productive and money capital. In the case of extraverted accumulation, the direction of extraversion matters a great deal. Even a mixture of some elements of export orientation and import dependence might exist." (Becker et al, 2010: 3-7) 
European countries, with the exception of Poland, are deeply affected by the economic crisis, which leads to a decline in growth (World Bank Databank 2017a). The subsequent economic recession has caused in most of the countries an increase in unemployment (World Bank Databank 2017b) and has fostered social insecurity, distrust in political parties and institutions among many citizens. The neoliberal economic transformation and the peripheralisation of Central and Eastern Europe have jointly increased social inequality, and so created the potential for conflicts and political protest within each country.

\section{CRISIS-PRONE DEVELOPMENT IN THE SPHERE OF SOCIETY}

an important outcome of the economic transformation was the rapid increase in social inequality, which has shaped Central and Eastern European societies until this day. Uneven points of departure for different societal groups has caused an unequal distribution of former state property (Szelényi 2008). The first poststate socialist governments were keen to pursue a neoliberal economic policy including the reduction of price controls, liberalisation of foreign trade and the development of a private financial sector (Desai 1997, Roaf et al. 2014). Speaking with the former Russian president Boris Yeltsin, the official goal of the economic policies was to make the reforms "irreversible" (Yeltsin 1994: 235). Therefore, their implementation had to occur as quickly and radically as possible ("shock-therapy"). The privatisation process, partially organized in non-transparent and corrupt procedures, produced a new class of capitalist businesspeople. At the same time, the so-called "shock-therapy" led to a dramatic increase in social inequality (Lane 2011).

A second crucial aspect of the economic transformation process was the reorganisation of the welfare state. Both the education and the welfare sectors were predominantly privatised. Pensions or unemployment benefits were not adjusted according to inflation nor the needs of the population. In fact, one important outcome of the peripheralisation process was that Central and Eastern European countries could not maintain their former level of social spending, which triggered an increase in social inequality.

Against the backdrop of the great expectations which sprouted in the early 1990s, citizens' disappointment in terms of not benefiting from the transformation led to frustration with politics, demolished support for democracy and has made citizens more prone to following populist politicians (Ulram-Plasser 2003, Voicu et al. 2016). The so-called losers of the transformation such as the elderly, people with lower education and (unskilled) workers have been particularly affected by this development. If the political elite continues to be unable or unwilling to tackle these issues properly, the legitimacy of democracy will continue being undermined, as political participation requires a minimum of social security as regards its citizens (Segert 2010: 32-35). Without a more equal distribution of economic resources organised by a stronger welfare state, social inequality will still increase and therefore, the social basis for democracy in terms of political equality is threatened, which heavily contributes to the often-discussed crisis of representative democracy (ibid: 38-39).

Concerning the general crisis-prone development since 1989, democratisation has remained predominantly restricted to civic rights and the adoption of formal procedures (e.g. elections) and institutions. We argue that economic decline and impoverishment of broad parts of the population have effectively impeded democratic consolidation. Disregarding a policy of social welfare as an integral part of democracy has raised distrust in political and economic elites, and especially institutions in the entire region (Lovell, 2001). 


\section{PROTEST AS AN INDICATOR FOR MULTIPLE CRISES?}

in the following part, we elaborate more specifically on the connection between protest and crisisprone development and argue why protest is an indicator for multiple crises. The preceding paragraphs show crises in the spheres of politics, economy and society, which are rooted in the development models emerging from the transformation process. However, so far, the relation between the spheres and protest movements remains rather unclear. In order to elaborate our argument and specify the connection between the spheres of crisis-prone development, we draw upon the concept of "multiple crises". Demirović et al. (2011) developed this approach in order to grasp the intertwined political, economic and societal changes, which have occurred particularly since the financial and economic crisis in 2008. The strength of the concept of "multiple crises" is that it goes beyond the realm of politics by including the economic and the societal dimension. Demirović et al. seek to contribute to a better understanding of societal development in Western Europe and North America driven by neoliberal polices. According to them, various crisis phenomena are rooted in the contradictions of the capitalist mode of production. A recent example would be the implementation of austerity policies, which increase social inequality and poverty. For example, the mandatory retiring age increases, public sector employment is drastically reduced and social standards (pensions, unemployment, the health and education sectors) gradually deteriorate (Demirović, 2013: 197). The deterioration of social standards is presented as a necessary precondition to overcome the economic crisis. At the same time, the well-off part of society is still able to increase their financial benefits. According to Demirović, democracies and their political representatives fail to regulate the financial markets. Austerity policies favour the latter, leading to growing social inequality as well as distrust and dissatisfaction with democratic institutions and procedures. In order to ensure that austerity policies can proceed, technocratic governments increasingly replace democratic procedures and impose strict budgetary controls (ibid: 196). Demirović et al. (2011) claim that the economic crisis is embedded in a broader crisis of societal development and intensifies the already existing political crisis. The declining importance of traditional democratic institutions (parliaments, and their representatives, parties and members of parliament), leads to a crisis of representation. Demirović et al. also describe a more profound erosion of democratic systems due to the gradual cutback of the welfare state; similar to the spheres of the transformation in Central and Eastern Europe since 1989, the crisis in one sphere evolves a special dynamic affecting the other, which increases already existing contradictions (ibid: 11-28).

Regarding Central and Eastern Europe, authors such as Attila Ágh or Dieter Segert link the development since 1989 to crisis-prone development. Ágh frames the development since 1989 as a "triple crisis" (2015). This consists of: (1) the social consequences of the transformation; (2) the subsequent decline in support of democracy by the citizens; (3) and citizens' disappointment with the EU in terms of improving their individual living conditions. Similar to Ágh, Segert stresses the social costs of the transformation as well as a high level of disappointment. By analysing the effects of the transformation, Segert argues that the region can be understood as a "laboratory" for testing "social resilience" of democracy (Segert 2010). Our argument is in line with authors like Ágh or Segert, but goes beyond their understanding of crisis-prone development, which is predominantly focused on political developments. In the following part, we go through the spheres of crisis- 
prone development identified previously, we highlight the latest developments since 2008, and discuss their impact on protests.

\section{The political crisis}

the political crisis consists of two interconnected crises: a crisis of representation and a crisis of liberal democracy. Concerning the former, low levels of trust in political parties, representatives and the parliament, a low level of partisanship and a high level of voter volatility characterise the relationship between the political elite and citizens. Studying growing populism in times of economic crisis, Kriesi and Pappas argue that the relationship between the political elite and citizens in Central and Eastern Europe was "estranged" long before the outbreak of the economic crisis in 2008, partially due to the high economic costs of the transformation (Kriesi \& Pappas, 2015: 3-4). In this sense, the effects of the economic crisis just added to the already existing crisis of representation and the general disenchantment with politics (Enyedi 2015: 236-237, Havlík 2015: 215-216). Bad governance, clientelism or corruption also contributed heavily to this supposed "estrangement". Since the outbreak of the economic crisis, this development has intensified. It has fostered distrust among the citizens towards democratic institutions and procedures, and increased the alleged gap between the political elite and the citizenry.

In terms of protest, the effects of the crisis of representation are ambivalent. Low trust in the political elite might encourage citizens to raise their voices directly and protest against certain policies or the government as a whole. Since the on-going crisis, protests against corruption and bad governance have been able to mobilise broad parts of the population, and have been especially noticeable in Bulgaria and Romania. At the same time, the high level of disenchantment, alienation and resignation might foster the already high level of political apathy. Citizens might perceive the political system as rather closed without many access points and possibilities to influence the decision-making process. If chances to trigger change through protest are low, the mobilisation of bystanders appears to be an onerous task. In this regard, the question of how the political elite reacts to protest is crucial. As the protest wave in Romania in early 2017 showed, one of the dominant strategies of the political elite to deal with protest is to reject their claims, discredit the protestors as illegitimate or foreign-financed, and try to proceed as planned.

In addition to the crisis of representation, Krastev (2016) states that Central and Eastern Europe deals with a "genuine crisis of liberal democracy", which is accelerated by the economic crisis and an increase of antiglobalisation and anti-cosmopolitan attitudes. In comparison to older democracies, weaker political institutions in the new democracies make Central and Eastern European countries more vulnerable when it comes to political crises. "Liberalism's failure to deliver" led many people to perceive the transformation to be a failure and evolved into a so-called "protest-vote democracy". In the case of Bulgaria, governments are less likely to be re-elected but still, economic policies hardly differ between governments (Krastev 2016: 36-38).

The crisis of liberal democracy contributes to the emergence of populist, nationalist and/or far-right parties and movements. The Polish politician Jarosław Kaczyński explained the success of his right-wing party Law and Justice (PiS) in 2005: "For us the crucial question was who would articulate and use politically the 
protest against all the powerful aspects of the economic reform" (cited in Ost 2007: 84). Parties such as PIS in Poland or Fidesz in Hungary share a deep suspicion for liberal democracy and propagate a new development model, "illiberal democracy" (Orbán 2014). This model is targeted at guaranteeing economic and political stability, prosperous development (for their respective national bourgeoisie) and independence from Western/EU dominance. Once in power, they do not hesitate to implement their policies, despite sometimes fierce protests. In order to stabilise economic and political development, the new elected governments in Hungary, Poland and to a lesser degree in Slovakia, centralize substantial resources within the state apparatus and transfer them to the executive branch. ${ }^{11}$ These steps often include revisions of national constitutions, control over public media and the judiciary (Bayer 2013) and establish an aggressive nationalist discourse against "enemies of the state". Moreover, they increase social spending for "the nation", often portrayed as part of the new national project, which is supposed to eventually lead the country into a better future (Szilágyi-Bozóki 2015). In this respect, such governments partly contradict the neoliberal agendas pursued by their predecessors. At the same time, they implement harsh anti-social policies against minorities, especially unemployed or homeless people and ethnic minorities (Muslims, refugees, Sinti and Roma).

Due to its refusal of liberal values such as human rights and liberal economic policies, the illiberal project becomes a real political alternative to liberal democracy. In this sense, the region experiences a crisis of liberal democracy, which is based on the high level of disappointment stemming from the development since 1989, the emergence of an alternative pathway to succeed in the "existing competition between the countries of the world" (Orbán, 2014) and a crisis of norms and values (e.g. the protection of universal human rights) (Dawson \& Hanley, 2016).

Regarding protest, the effects of the crisis of liberal democracy are again, ambivalent. Firstly, the incumbent governments in countries such as Hungary or Poland enjoy a certain level of popular support, which led to their election in the first place and which also manifests itself in protest in favour of the government and their policies. ${ }^{12}$ Protest against minorities, in particular LGBTI* issues, same-sex marriage or anti-abortion stances have increased over the past years. Anti-pluralism and a narrow understanding of who belongs to the nation appear to gain popular support. The refusal of liberal values ${ }^{13}$ is not only to be observed on the level of the political elite, but also in anti-pluralistic protests. Secondly, the illiberal project and its authoritarian facets are likely to trigger protest. As seen in Poland with the re-election of PIS in 2015 or the various protests against Fidesz over the past years, a certain proportion of citizens are willing to protest against such developments. Those citizens reject the turning away from liberal values and express their discontent with authoritarian tendencies or forms of bad governance, such as corruption.

11 The Orbán government was particularly keen on increasing its influence over the Hungarian central bank (Johnson-Barnes 2015)

12 In terms of mobilising popular support, the level of independence of public and private media outlets from the government matters in particular. Biased or one-sided reporting on governmental activities is likely to increase governmental support (Susánszky et al. 2016).

13 For a detailed discussion on liberal values and regional differences in culture, see Inglehart-Welzel 2010. 


\section{The economic crisis and its social consequences}

as Krastev states, liberal democracy is in crisis due to its failure to deliver. In particular, the economic crisis in 2008 contributed to this state of crisis. Similar to Southern Europe, Central and Eastern Europe has been severely affected by the economic crisis. The IMF bailed out financialised economies such as Latvia, Hungary and Romania (Kattel 2010, Lütz-Kranke 2014). In exchange, the countries pursued a strict monetarist economic policy. Other countries, such as Slovenia, Slovakia or Croatia, also applied austerity programs in order to counterbalance economic hardship. Like countries within the Eurozone, an austerity policy was presented as the only solution for effective crisis management. As a result, social standards deteriorated even further, deepening economic recession. Even though this development sparked widespread protests, governments in power (regardless of their political orientation) usually proceed with the austerity policies.

Concerning protest, the effects are again ambivalent. Harsh economic conditions and austerity measures foster voices of discontent. At the same time, such conditions hamper political participation, as many citizens face economic hardship. Regarding the former, Jacobsson (2015) argues viewing the latest protests as a cocktail consisting of growing anti-austerity voices against increasing social inequality in many countries all over the world and disenchantment rooted in domestic political crisis and declining satisfaction with parties and politicians. The increasing gap between the system of representative democracy and the daily life of the majority of the population, shaped by a deterioration of social standards, gives room for new protest movements. Musić adds that public outrage is directly linked to more than two decades of neoliberal reforms and failed modernization of the former state-socialist societies through integration the semi-peripheral region into the world market. The subjective feeling of stalemate and increased frustration by citizens and growing deindustrialisation are dominant effects of the crisis in South-East Europe; the latter pushing people into the informal sector (Musić 2013: 322-323, 328). Protests are triggered by the on-going economic crisis and the implemented austerity policy. At the same, they are a reaction to the region's crisis-prone development models.

In the case of Central and Eastern Europe, a lack of social security caused by the transformation since 1989 fosters citizens' retreat from institutionalised politics (i.e. participation in elections and parties), and triggers political apathy (Spöri 2015). Segert and Bos (2008) claim that turnout being in decline, growing political apathy, an increasing gap between the political elite and the people, high voter volatility and emerging populism can be explained by the societal division between winners and losers of the transformation (Segert 2008: 16-23). The pursued neoliberal role model has caused mainly negative effects for the majority of the population in terms of social security and welfare policy. Reducing the state's capacity and its institutions in the 1990s was the main cause of this trend for unregulated capitalism (Bos-Segert 2008: 334). In political terms, a vast number of citizens are economically deprived and do not have the means to interfere and participate in democratic processes as effectively as the political and economic elites. Segert argues that Central and Eastern Europe has served as a "laboratory" for a neoliberal policy agenda, including the recently implemented austerity measures, which has created a hostile environment for citizens to participate in.

Since the ecology of protest in Central and Eastern Europe appears to be ambivalent, we want to summarize why protest is both an expression of and a reaction to multiple crises. Protest is an extra-representational form 
of political participation (i.e. a direct expression of citizens' opinions). The existence of protest as such does not automatically indicate crises. We argue that increased protest participation is a reaction to the particular societal development in Central and Eastern Europe since 1989. Since the frequency of larger protests has increased over recent years and the issues tackled by the protests are very diverse, ranging from particular policies such as anti-austerity or anti-abortion to general protests against the government or the "corrupt elite", the current development model appears to be contested and in crisis. Protests are a result of a high level of distrust in the political elite, civil unrest in terms of individual economic hardship and disappointment, in terms of what Krastev (2016) called liberalism's failure to deliver. This "cocktail" of disenchantment, frustration and alienation stems from the manifold political, economic and societal changes since 1989, which we describe as "crisis-prone".

\section{OUTLOOK: PROTEST AND CRISIS IN CENTRAL AND EASTERN EUROPE}

The article scrutinizes crisis-prone development in Central and Eastern Europe since 1989 and the increased protest activity since the outbreak of the financial and economic crisis in 2008. In this theoretical paper, we stress the relation between structural problems and protest dynamics in the region and its countries. Focusing on the spheres of the economy, politics and society, we determine a common pattern of crisis-prone development models in Central and Eastern Europe. This pattern contributes to and reinforces the general outcomes of the transformation process. In particular, since the outbreak of the financial and economic crisis in 2008, these manifold outcomes were condensed in "multiple crises" sparking widespread protest throughout the region. Similar to a floating iceberg, we argue that the growing number of protests is just the visible tip of the crisis-prone development. The ecology of protest in the region is ambivalent. Many citizens face economic hardship and/or are politically apathetic and are therefore less likely to protest. Following Segert, we argue that Central and Eastern Europe can be understood as a "laboratory" for testing the "social resilience" of democracy. The pursued neoliberal role model has caused mainly negative effects for the majority of the population in terms of social security and welfare policy, creating a hostile environment for citizens to participate in.

At the same time, a growing number of citizens appear to be more willing to raise their voices directly in public, which is triggered by diverse factors such as the great disenchantment with the performance of the democratic system and manifold disappointments since 1989. In many cases, as a reaction to measures taken by governments to overcome the economic crisis (e.g. austerity policies), widespread and creative protests have emerged. The sheer number of protests flags a deeper, more profound crisis affecting multiple societal spheres (politics, economy, society) within Central and Eastern European societies, which is closely connected to the peripheral development models.

After almost 30 years of transformation, and in particular after the economic crisis severely influenced many people's social security and future perspectives, some citizens appear to be more likely to be mobilised and take part in protests, which tackle the symptoms of the crisis-prone development model. By protesting against diverse issues, involved citizens experience forms of political participation beyond classic representation such as plenary meetings, direct democracy and social movements. 
At the same time, we can observe the increasing success of far-right movements. Benefiting from and reinforcing the established nationalising discourses, the increasing social inequality and the distrust in democratic institutions, these movements also have to be analysed as a reaction to the unstable and peripheral development. The future will show the extent to which those protests reshape the way Central and Eastern European societies are currently organised. 


\section{REFERENCES}

Ágh, A. (2015) The Triple Crisis in the New Member States: The Historical Trajectory of NMS-8 in the Past Quarter Century. Southeastern Europe, 39(3), 294-317. http://dx.doi.org/10.1163/18763332-03903001.

Barnes, S. H. (2006) The Changing Political Participation of Postcommunist Citizens. International Journal of Sociology, 36(2), 76-98.

Bayer, J. (2013) Emerging Anti-pluralism in New Democracies - the Case of Hungary. Österreichische Zeitschrift für Politikwissenschaft, 42(1), 95-110.

Becker, J. - Jäger, J. - Leubolt, B. - Weissenbacher, R. (2010) Peripheral Vulnerability to Crisis: A Regulationist Perspective. Competition and Change, 14(3-4), 225-247.

Becker, J. - Jäger J. (2012) Integration in Crisis: A Regulationist Perspective on the Interaction of European Varieties of Capitalism. Competition and Change, 16(3), 169-187.

Bērzinš, J. (2014) Ignacio Rangel Visits Latvia: Crisis and the Political Economy of Duality. Debatte: Journal of Contemporary Central and Eastern Europe, 22(1), 81-102.

Bos, E. - Segert, D. (2008) Osteuropa als Trendsetter? Parteiensysteme in repräsentativen Demokratien unter mehrfachem Druck. In Bos E. - Segert D. (eds.) Osteuropäische Demokratien als Trendsetter? Parteien und Parteiensysteme nach dem Ende des Übergangsjahrzehnts. Opladen \& Farmington Hills: Barbara Budrich, 323-336.

Braun, D. - Hutter, S. (2014) Political trust, extra-representational participation and the openness of political systems. International Political Science Review, 37(2), 151-165.

Brubaker, R. (2011) Nationalizing states revisited: projects and processes of nationalization in post-Soviet states. Ethnic and Racial Studies, 34(11), 1,785-1,814

Chesters, G. - Welsh, I. (2011) Social movements: the key concepts. New York, NY: Routledge.

Dawson, J. - Hanley, S. (2016) What's Wrong with East-Central Europe? The Fading Mirage of the "Liberal Consensus". Journal of Democracy, 27(1), 20-34.

Demirović, A. - Dück, J. - Bader, P. (2011) VielfachKrise. Im finanzmarktdominierten Kapitalismus. Hamburg: VSA-Verlag.

Demirović, A. (2013) Multiple Krise, autoritäre Demokratie und radikaldemokratische Erneuerung. PROKLA, 43(2), $193-215$.

Desai, P. (ed.) (1997) Going Global. Transition from Plan to Market in the World Economy. Cambridge: MIT Press.

Diamond, L. - Fukuyama, F. - Horowitz, D. L. - Plattner, M. F. (2014) Reconsidering the Transition Paradigm. Journal of Democracy, 25(1), 86-100.

Drahokoupil, J. (2008) The Rise of the Comprador Service Sector. The Politics of State Transformation in Eastern Europe. Polish Sociological Review, 57(2), 175-189.

Elster, J. - Offe, C. - Preuss, U. K. (1998) Institutional design in post-communist societies: rebuilding the ship at sea. Cambridge, U.K.; New York, NY, USA: Cambridge University Press.

Enyedi, Z. (2015) Plebeians, Citoyens and Aristocrats or Where is the Bottom of Bottom-up? The Case of Hungary. In Kriesi H. and Pappas T. S. (eds.) European Populism in the Shadow of the Great Recession. Colchester: ECPR Press, 235-250.

Galgóczi, B. (2009) Central and Eastern Europe Five Years After. From "Emerging Europe" to "Submerging Europe"? Etui Policy Brief Issue 4/2009. Available at: www.etui.org/Publications2/Policy-Briefs/European-Economic-Employment-and-Social-Policy/ Central-Eastern-Europe-five-years-after-from-emerging-Europe-to-submerging-Europe [Accessed: 13/11/2017].

Harrebye, S. - Ejrnæs, A. (2015) European patterns of participation - How dissatisfaction motivates extra-parliamentary activities given the right institutional conditions. Comparative European Politics, 13(2), 151-174.

Havlík, V. (2015) The Economic Crisis in the Shadow of Political Crisis: The Rise of Party Populism in the Czech Republic. In Kriesi H. and Pappas T. S. (eds.) European Populism in the Shadow of the Great Recession. Colchester: ECPR Press, 199-216.

Hooghe, M. - Quintelier, E. (2014) Political participation in European countries: The effect of authoritarian rule, corruption, lack of good governance and economic downturn. Comparative European Politics, 12(2), 209-232.

Howard, M. M. (2002) The Weakness of Postcommunist Civil Society. Journal of Democracy, 13(1), 157-169.

Inglehart, R. - Welzel, C. (2010) Changing Mass Priorities: The Link between Modernization and Democracy. Perspectives on Politics, 8(2), 551-567. https://doi.org/10.1017/S1537592710001258.

Ishiyama, J. T. (1997) Transitional Electoral Systems in Post-Communist Eastern Europe. Political Science Quarterly, 112(1), 95-115.

Jacobsson, K. (2015) Urban grassroots movements in Central and Eastern Europe. Burlington: Ashgate Pub.

Janmaat, J. G. (2006) Civic Culture in Western and Eastern Europe. European Journal of Sociology / Archives Européennes de Sociologie, 47(3), 363-393. https://doi.org/10.1017/S0003975606000129. 
Johnson, J. - Barnes, A. (2015) Financial nationalism and its international enablers: The Hungarian experience. Review of International Political Economy, 22(3), 535-569. http://dx.doi.org/10.1080/09692290.2014.919336.

Kattel, R. (2010) Financial and economic crisis in Eastern Europe. Journal of Post Keynesian Economics, 33(1), 41-60.

Killingsworth, M. (2012) Civil Society in Communist Eastern Europe. Opposition and Dissent in Totalitarian Regimes. Colchester: ECPR Press.

Kitschelt, H. (1995) Formation of Party Cleavages in Post-Communist Democracies: Theoretical Propositions. Party Politics, 1(4), 447-472.

Kornai, J. (2006) The great transformation of Central Eastern Europe. Success and disappointment. Economics of Transition, 14(2), 207-244. https://doi.org/10.4324/9780203827345

Kostelka, F. (2014) The State of Political Participation in Post-Communist Democracies: Low but Surprisingly Little Biased Citizen Engagement. Europe-Asia Studies, 66(6), 945-969. http://dx.doi.org/10.1080/09668136.2014.905386.

Krastev, I. (2016) Liberalism's Failure to Deliver. Journal of Democracy, 27(1), 35-38.

Kriesi, H. - Pappas, T. S. (2015) Populism in Europe During the Crisis: An Introduction. In Kriesi H. - Pappas T. S. (eds.) European Populism in the Shadow of the Great Recession. Colchester: ECPR Press, 1-19.

Lane, D. (ed.) (2011) The Transformation of State Socialism. System Change, Capitalism or Something Else? New York: Palgrave Macmillan.

Letki, N. (2004) Socialization for Participation? Trust, Membership, and Democratization in East-Central Europe. Political Research Quarterly, 57(4), 665-679.

Lovell, D. W. (2001) Trust and the politics of postcommunism. Communist and Post-Communist Studies, 34(1), 27-38.

Lütz, S. - Kranke, M. (2014) The European rescue of the Washington Consensus? EU and IMF lending to Central and Eastern European countries. Review of International Political Economy, 21(2), 310-338.

Mishler, W. - Rose, R. (1997) Trust, Distrust and Skepticism: Popular Evaluations of Civil and Political Institutions in Post-Communist Societies. The Journal of Politics, 59(2), 418-451.

Musić, G. (2013) Between Facebook and the Picket Line: Street Protests, Labour Strikes and the New Left in the Balkans. Journal of Contemporary Central and Eastern Europe, 21(2-3), 321-335.

Myant, M. - Drahokoupil, J. (2013) Transition Economies after the Crisis of 2008: Actors and Policies. Europe-Asia Studies, 65(3), 373-382. http://dx.doi.org/10.1080/09668136.2013.779459.

Naimark, N. M. - Gibianskii, L. (1997) The Establishment Of Communist Regimes In Eastern Europe, 1944-1949. Boulder, Colo.: Westview Press.

Nölke, A. - Vliegenthart, A. (2009) Enlarging the Varieties of Capitalism. The Emergence of Dependent Market Economies in Eastern Europe. World Politics, 61(4), 670-702.

Norris, P. (2002) Democratic Phoenix: Reinventing Political Activism. Cambridge, UK; New York, NY: Cambridge University Press.

Offe, C. (1991) Das Dilemma der Gleichzeitigkeit. Demokratisierung und Marktwirtschaft in Osteuropa. Merkur, 45(4), $279-292$.

Orbán, V. (2014) Prime Minister Viktor Orbán's Speech at the 25th Bálványos Summer Free University and Student Camp. Available at: www.kormany.hu/en/the-prime-minister/the-prime-minister-s-speeches/prime-minister-viktor-orban-s-speech-at-the-25thbalvanyos-summer-free-university-and-student-camp [Accessed: 13/11/2017].

Ost, D. (2007) Social Forces and the Post-communist Transition: Why Labour Turns Right. In: Lane, D. (Ed.): The Transformation of State Socialism. System Change, Capitalism or Something Else? Houndsmills; Palgrave Macmillan, 77-91.

Pop-Eleches, G. - Tucker, J. A. (2013) Associated with the Past? Communist Legacies and Civic Participation in Post-Communist Countries. East European Politics \& Societies, 27(1), 45-68. https://doi.org/10.1177\%2F0888325412465087.

Popławski, K. (2016) The role of Central Europe in the German economy. The political consequences. Ośrodek Studiów Wschodnich (OSW) Report. Available at: www.osw.waw.pl/en/publikacje/osw-report/2016-05-16/role-central-europe-german-economypolitical-consequences [Accessed: 13/11/2017].

Roaf, J. - Atoyan, R. - Joshi, B. - Krogulski, K. (2014) 25 Years of Transition: Post-Communist Europe and the IMF. Regional Economic Issues Special Report. Available at: www.imf.org/external/pubs/ft/reo/2014/eur/eng/pdf/erei_sr_102414.pdf [Accessed: 13/11/2017].

Schreiner, J. (2010) Developments in Selected CESEE Countries. After the Drought - Tentative Economic Stabilisation in the CESEE Region. Focus on European Economic Integration Q2/10. Available at: www.oenb.at/dam/jcr:95015e1d-b8a7-411b-8c26565a9feb3e0d/feei_2010_q2_recent_developments_tcm16-193977.pdf [Accessed: 13/11/2017]. 
Segert, D. (2008) Parteien und Transformation in Osteuropa nach dem Ende des Übergangsjahrzehnts. In Bos E. and Segert D. (eds.) Osteuropäische Demokratien als Trendsetter? Parteien und Parteiensysteme nach dem Ende des Übergangsjahrzehnts. Opladen \& Farmington Hills: Barbara Budrich, 11-32.

Segert, D. (2010) Osteuropa nach 1989 - ein Labor für die soziale Belastbarkeit unserer Demokratie? WISO, 33(3), $29-42$.

Segert, D. (2013) Understanding the "Footprint of State Socialism" in East Central European Post-Socialism. Human Affairs, 23(3), 416-428. https://doi.org/10.2478/s13374-013-0138-0.

Spöri, T. (2015) ... To be Continued? Challenging the Cultural Legacy Argument in Central and Eastern Europe. CEU Political Science Journal, 10(1), 84-111.

Susánszky, P. - Kopper, A. - Tóth, G. (2016) Pro-government demonstrations in Hungary - citizens' autonomy and the role of the media, East European Politics, 32(1), 63-80. http://dx.doi.org/10.1080/21599165.2015.1128900.

Szelényi, I. (2008) Making Capitalism without Capitalists: Revisited. International Political Anthropology, 1(1), $139-148$.

Szilágyi, A. - Bozóki, A. (2015) Playing It Again in Post-Communism: The Revolutionary Rhetoric of Viktor Orbán in Hungary. Advances in the History of Rhetoric, 18(1), 153-166.

Tanasoiu, C. (2013) Homo Post-communistus: Portrait of a Character in Transition. Perspectives on European Politics and Society, 14(4), 599-612. http://dx.doi.org/10.1080/15705854.2013.793536.

Teorell, J. - Torcal, M. - Montero, J. R. (2007) Political participation: mapping the terrain. In Van Deth, J. - Montero, J. R. - Westholm, A. (eds.) Citizenship and Involvement in European Democracies: A Comparative Analysis. London: Routledge, 334-357.

Ulram, P. A. - Plasser, F. (2003) Political Culture in East-Central and Eastern Europe: Empirical Findings 1990-2001. In Pollack, D. Jacobs, J. - Müller, O. - Pickel, G. (eds.) Political Culture in Post-Communist Europe. Attitudes in new democracies. Aldershot: Ashgate, 31-46.

Voicu, M. - Mochmann, I. C. - Dülmer, H. (2016) Values, Economic Crisis and Democracy. London: Routledge.

Wessels, B. - Klingemann, H. D. (2006) Parties and Voters - Representative Consolidation in Central and Eastern Europe? International Journal of Sociology, 36(2), 11-44.

World Bank. Databank (2017a) GDP per capita growth (annual\%). Available at: http://data.worldbank.org/ [Accessed: 13/11/2017].

World Bank. Databank (2017b) Unemployment, total (\% of total labor force) (national estimate). Available at: http://data.worldbank. org/ [Accessed: 13/11/2017].

Yeltsin, B. (1994) Zapiski prezidenta [Chronicles of a president]. Moscow: Ogonek. 